\title{
PERSEPSI KONSUMEN MENGENAI SUASANA LINGKUNGAN TOKO RITEL TERHADAP KETERTARIKAN PELANGGAN TOKO RITEL
}

\author{
Khusniyah Purwani
}

\section{Abstract}

The focus of this research reveal the perceptions of retail customers to see the environmental atmosphere shop to shop choices that will ultimately affect the interest' of customers shop. Indicators store environment seen through social factors, store design and in-store music. Store selection criteria will be detailed through consumer perceptions of service clerks, quality of merchandise, money (as seen from monetary units), cost (time and effort), and psychic costs of consumers. These factors affect the perception of consumers about the value of the merchandise sold in stores as well and at a late stage will affect the interest of customers shop.

A total of 190 respondents spread across various retail stores in Yogyakarta Special Region in the survey using a questionnaire. Most respondents who netted the students or students. Field survey methods used to collect data and data analysis using structural equation modeling-analysis of moment structures (AMOS). AMOS though results beginning with the confirmatory factor analysis showed that the goodness of fit test of this model fit, so this research model is acceptable. Causality test results indicate that the hypothesis of significant eleven and nine hypotheses were not significant. So it can be concluded that, overall, the hypothesis proposed in this study proved.

Key word : merchandise, store employee perceptions, store design perceptions, store ambient perceptions, store choice criteria, merchandise value perceptions, store patronage intentions.

Khusniyah Purwani; Staf Pengajar, Program Diploma 3 Ekonomi, UII 


\section{PENDAHULUAN}

Daerah Istimewa Yogyakarta (DIY) sebagai kota multi predikat sangat tepat untuk dicermati perkembangan dan pertumbuhannya. Predikat sebagai kota pendidikan, kiblatnya pendidikan, kota gudeg, kota perjuangan, dan sebagai kota kebudayaan sudah diketahui oleh seluruh masyarakat Indonesia. Predikat berikutnya yang tidak kalah menarik adalah sebagai kota ritel. Predikat ini-menarik untuk di cermati lebih jauh terlebih melihat karakteristik konsumen yang heterogen, dengan jumlah penduduk keseluruhan 45 juta akan menjadi konsumen potensial dan perkembangan bisnis ini yang cukup pesat di DIY. Tidak hanya bisnis ritel lokal yang sudah muncul dari masyarakat lokal sendiri tetapi juga ritel asing. Globalisasi ternyata telah membawa perubahan bagi kota ini dan kota ini akan tetap menyambutnya sebagai perubahan yang positif.

Bisnis ritel merupakan kegiatan bisnis yang terlibat dalam penjualan barang dan jasa kepada para konsumen untuk pemakaian pribadi, keluarga atau rumah tangga secara langsung (Berman, 1995). Bisnis ritel berupaya untuk memenuhi kebutuhan dan keinginan konsumen secara langsung. Dalam pemasaran peritel akan menduduki channel terakhir dalam saluran distribusi, dan orang-orang yang terlibat dalam pergerakan fisik dan transfer kepemilikan barang dan jasa dari produsen kepada konsumen, akan melayani konsumen secara langsung tanpa perantara (Thoyib, Usman 1998, h.20). Bisnis ritel berkembang dan maju karena konsumen ritel yang jumlahnya sangat banyak. Sebagian besar konsumen melakukan pembelian dengan rata-rata jumlah pembelian setiap transaksi kecil, sering pula melakukan pembelian yang sifatnya tidak terencana sebelumnya. Oleh karena itu penting untuk memahami pemakaian strategi ritel yang terkait dengan pemajangan barang dagangan (merchandise display) dan penataan layout lingkungan toko (store environment display) untuk menarik minat konsumen. Hal ini menarik untuk mencermati strategi yang digunakan sebagai variabel perangsang perhatian pelanggan ritel.

Penekanan riset ini adalah menguji sebuah model penelitian mengenai persepsi suasana/atmosfir lingkungan toko terhadap kriteria keputusan pemilihan toko bagi konsumen. Riset ini mengacu pada riset sebelumnya yakni "the influence of multiple store environment cues on perceived merchandise value and patronage intentions". Model pilihan toko yang komprehensif digunakan meliputi 1) tiga bentuk suasana lingkungan toko sebagai variabel exogeneous, 2) kriteria pilihan toko sebagai variabel yang memediasi (mediating constructs), dan 3) perhatian pelanggan toko sebagai variabel endogeneous (Julie, et.al., 2002): Ada beberapa hipotesis dari model yang memang tidak ikut uji, yakni $\mathrm{H} 2 \mathrm{c}, \mathrm{H} 3 \mathrm{c}, \mathrm{H} 5 \mathrm{a}, \mathrm{H} 8 \mathrm{a}$ dan $\mathrm{H} 8 \mathrm{~b}$.

Permasalahan yang diangkat dalam penelitian ini adalah menguji model penelitian yakni bagaimanakah persepsi konșumen téntang karyawan toko (store 
employee perceptions), desain dan layout toko (store design perceptions), situasi/atmosfir toko (store ambient perceptions) dan pengaruhnya terhadap keputusan kriteria pemilihan toko (store choice criteria) dan nilai barang dagangan (merchandise value perceptions), serta pengaruhnya terhadap perhatian pelanggan toko (store patronage intentions).

Dengan demikian tujuan riset ini adalah untuk menganalisa dan mengidentifikasi persepsi konsumen mengenai karyawan toko, desain dan layout toko, situasi/atmosfir toko terhadap keputusan kriteria pemilihan toko, dan pengaruhnya terhadap perhatian pelanggan toko ritel.

Secara garis besar hasil riset ini akan bermanfaat di dalam penerapan strategi ritel dan fungsi-fungsi manajerial di supermarket/hypermarket. Secara teoretik, riset ini merupakan pengujian atau verifikasi teori dari variabel-variabel yang dapat mempengaruhi konsumen dalam mempersepsikan nilai barang dagangan, dalam melihat, dan memilih supermarket/hypermarket. Situasi pelayanan oleh karyawan toko, desain, layout dan pemajangan barang dagangan di toko, serta suasana atmosfir toko akan menjadi pertimbangan konsumen dalam menilai barang dagangan yang tersedia di supermarkethypermarket. Sumbangan lainnya adalah bahwa hasil riset ini diharapkan dapat menjelaskan variabel-variabel yang menjadi fokus utama perhatian pelanggan toko tertarik ke supermarket/hypermarket. Secara praktis hasil penelitian ini dapat bermanfaat bagi peritel- peritel kecil seperti mini market, supermarket dan swalayan-swalayan lokal yang secara langsung melayani konsumen akhir, sebagai bentuk pelayanan publik kepada masyarakat. Tidak menutup kemungkinan hasil penelitian ini dapat memberikan saran bagi peritel baru yang akan masuk ke bisnis ritel consumergoods.

\section{TINJAUAN TEORI HIPOTESIS}

\subsection{Kerangka Penelitian}

Kerangka penelitian (lihat gambar) yang digunakan mengacu pada model penelitian Julie Baker dan A Parasuraman (2002), yaitu A Conceptual Model of the Prepurchase Process of Assessing a Retail Outlet on the Basis of Environmental Perceptions. Model penelitian ini menggabungkan psikologi lingkungan dan kognisi konsumen (Zeithamal's, 1988) yaitu bahwa persepsi konsumen akan nilạ seperti keputusan-keputusan pembelian didasarkan pada persepsi konsumen terhadap kualitas produk (yang diperoleh konsumen dari pertukaran) dan harga (yang terdiri dari aspek moneter dan non moneter yang konsumen keluarkan dalam proses pertukaran/ pembelian). Model ini juga mengadopsi model yang diajukan oleh Zeithaml (1988) tentang penataan suatu ritel, dan mengakomodasi konsep Baker (1998) dan Bitner (1992) mengenai suatu lingkungan pelayanan dapat mempengaruhi proses 
pengambilan keputusan yang dilakukan oleh konsumen.

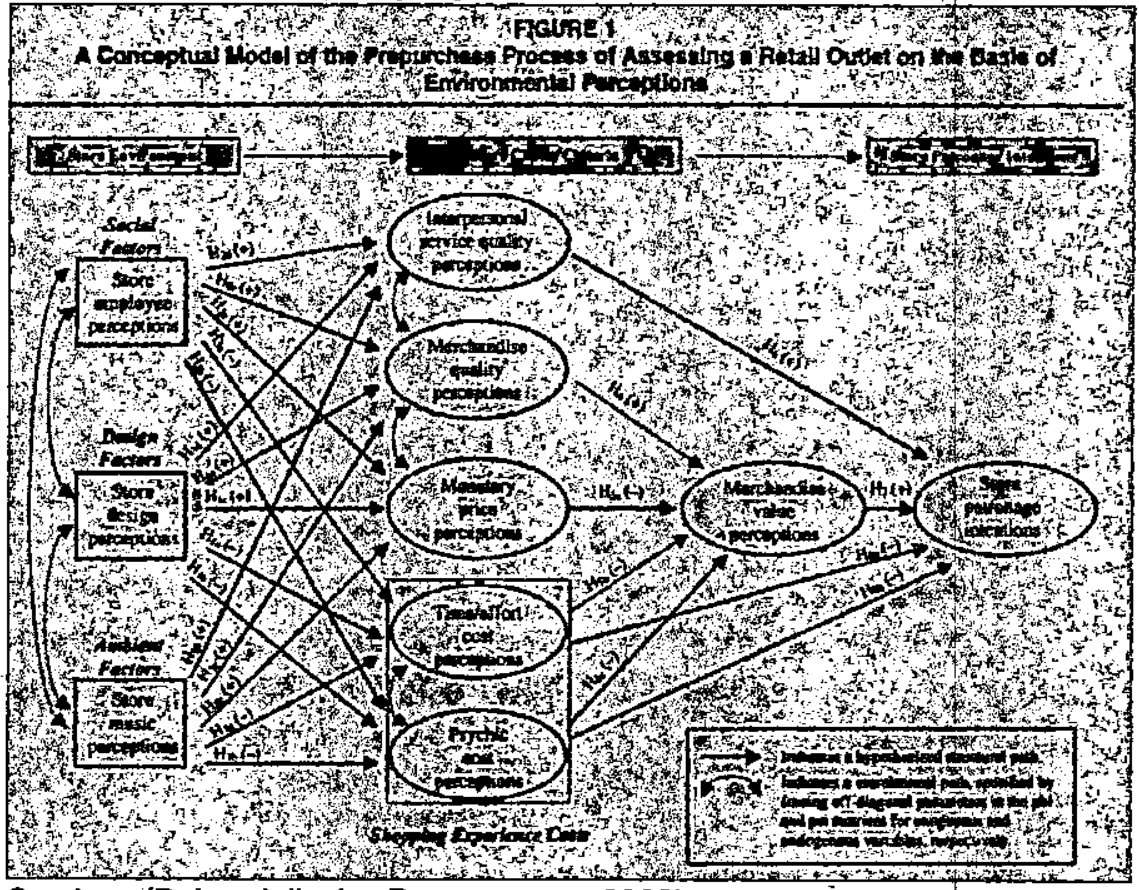

Sumber : (Baker, Julie dan Parasuraman, 2002)

Secara keseluruhan model ini mengajukan dimensi-dimensi lingkungan toko yang berpengaruh terhadap persepsi.

Secara keseluruhan model ini mengajukan dimensi-dimensi lingkungan toko yang berpengaruh terhadap persepsi konsumen tentang kriteria keputusan pemilihan toko, seperti kualitas pelayanan karyawan toko secara personal, biaya-biaya yang dikeluarkan selama berbelanja (shopping experience costs), (Wheatley, dan John, 1977), dan nilai barang dagangan (merchandise value) yang dipengaruhi oleh faktor kualitas, harga dan biaya pengalaman berbelanja yang diterima konsumen serta persepsinya. Tahap berikutnya adalah bahwa hal itu akan mempengaruhi maksud ketertarikan/perhatian pelanggan terhadap toko (supermarket/hypermarket).

Persepsi konsumen dalam model ini menunjuk pada kesimpulan mengenai tingkat kualitas, tingkat harga, dan nilai yang diharapkan oleh konsumen didalam toko dengan mendasarkan kepada petunjuk atau tandatanda atmosfir lingkungan toko. Model ini akan.lebih tepat ketika konsumen potensial toko terșebut telah memiliki pengalaman sebelumnya mengenai penawaran-penawaran yang telah dilakukan toko, dan juga ketika suatu toko 
itu pernah atau sedang dalam tahap pembenahan kembali, yang dengan demikian memberikan kepada konsumen petunjuk tentang suasana lingkungan toko yang baru.

Empat aspek yang unik dari model ini yang membedakan dari model sebelumnya adalah:

1) Model ini menganggap bahwa biaya yang dikeluarkan dalam usahanya

- untuk berbelanja biaya waktu untuk berbelanja dan biaya psikis yang dikeluarkannya, serta menguji pengaruhnya terhadap variabel maksud/perhatian pelanggan toko (store patronage intentions).

Waktu/usaha yang dikeluarkan oleh konsumen adalah waktu yang dibutuhkan oleh konsumen, waktu yang diluangkan oleh konsumen pada saat berbelanja di sebuah toko. Waktu/usaha yang dikeluarkan oleh konsumen itu akan berpengaruh terhadap perhitungan biaya total yang dikeluarkan konsumen saat berbelanja. Biaya psikis adalah biaya-biaya yang dikeluarkan oleh konsumen yang berkaitan dengan tekanan mentalnya sebagai konsumen atau emosi konsumen selama proses berbelanja. Lingkungan psikologis konsumen dimaksudkan adalah pemahaman akan biaya-biaya yang memberikan reaksi negatif bagi konsumen terhadap toko/lingkungan toko.

2) Model penelitian ini lebih menekankan pada bagaimana seorang konsumen menerima tingkat harga umum terhadap kelompok produk yang dijual di dalam toko dengan mendasarkan pada apa yang konsumen cermati di dalam lingkungan toko. Kelompok produk dikhususkan pada barang dagangan (merchandise), untuk membedakannya dari merek atau produk spesifik. Nilai barang dagangan (merchandise) merupakan fungsi dari harga barang dagangan yang diterima, kualitas barang dagangan dan biaya-biaya yang 'dikeluarkan untuk berbelanja.

3) Model nilai (Zeithaml, 1988) lebih memfokuskan pada evaluasi kualitas produk. Tetapi dalam bisnis ritel, konsumen akan mengevaluasi kualitas pelayanan seperti pada saat konsumen mengevaluasi kualitas barang dagangan. Oleh karena itu model penelitian ini memasukkan kedua unsur kualitas yang saling berhubungan tetapi merupakan dua komponen yang berbeda. Kualitas pelayanan merupakan aspek penting dalam berbelanja di dalam toko ritel yaitu kualitas interaksi dari karyawan dan konsumen toko ("interpersonal service quality"). Termasuk di dalamnya adalah pemberian pelayanan yang baik, pelayanan barang dagangan dengan cepat dan perhatian secara khusus dari karyawan toko.

4) Penelitian ini akan menguji hubungan"antar variabel secara simultan seperti yang tersaji dalam model penelitian di atas. Model ini menyajikan dua puluh (20) hipotesis yang saling berhubungan satu dengan lainnya. Dukungan empiris dan teori dari model yang digunakan dalam riset ini telah banyak 
dilakukan peneliti pemasaran, dengan hanya menguji atau memaparkan sebagian demi sebagian dari hipotesis yang ada maupun secara keseluruhan. Hipotesis tersebut disebutkan satu persatu yaitu :

\subsection{HIPOTESIS}

\subsubsection{Lingkungan Toko (Store Environment) \\ 2.2.1.1. FaktorSosial (Store Employee)}

Seluruh hipotesis mengenai pengaruh lingkungan toko ini didasarkan pada ketiga teori yang saling berhubungan yaitu teori inferensi, teori skema dan teori affordance. Teori inferensi menyatakan bahwa orang berpendapat mengenai ketidaktahuannya dengan berdasarkan pada informasi yang diterimanya dari beberapa petunjuk yang tersedia untuk mereka. Teori skema menyatakan bahwa secara kognitif struktur dari susunan pengetahuan sebelumnya, digambarkan dalam bentuk pengalamannya, yang memberi petunjuk mengenai inferensi dan perkiraan. Hal ini membantu membentuk harapan seorang konsumen dalam cakupan yang ambigu/ yang baru. Teori affordance menyarankan bahwa orang menerima lingkungan fisiknya dengan penuh makna seperti persepsi yang mengandung informasi langsung kepadanya.

Menyatakan bahwa orang berpendapat mengenai ketidaktahuannya dengan berdasarkan pada informasi yang diterimanya dari beberapa petunjuk yang tersedia untuk mereka. Teori skema menyatakan bahwa secara kognitif struktur dari susunan pengetahuan sebelumnya, digambarkan dalam bentuk pengalamannya, yang memberi petunjuk mengenai inferensi dan perkiraan. Hal ini membantu membentuk harapan seorang konsumen dalam cakupan yang ambigu/ yang baru. Teori affordance menyarankan bahwa orang menerima lingkungan fisiknya dengan penuh makna seperti persepsi yang mengandung informasi l angsung ke pad a n y a

Teori-teori ini juga secara bersama-sama menyatakan bahwa konsumen cenderung untuk merancang keadaan/suasana toko dan karyawan toko ketika menilai sebuah toko, karena mereka percaya bahwa keadaankeadaan/ petunjuk itu menggambarkan informasi yang dapat dipercaya mengenai atribut-atribut yang terkait dengan 
produk seperti kualitas, harga dan pengalaman berbelanja (Bitner, 1992). Bukti empiris mendukung ide bahwa informasi tentang suasana lingkungan toko mempengaruhi persepsi konsumen tentang penyedia jasa layanan dan membantu konsumen dalam menggolongkan perusahaan-perusahaan ritel/ supermarket/hypermarket (Akhter, 1994).

\subsubsection{Faktor Desain Toko (Store Design)}

Seperti yang dinyatakan dalam teori psikologi lingkungan, sebagian besar peran penting lingkungan supermarkethypermarket adalah dapat memfasilitasi tujuan pemilik, seperti kenyamanan, kemudahan mencari barang dan keluar dari toko dengan cepat. Layout toko merupakan salah satu contoh dari petunjuk desain (design cue) yang mungkin mempengaruhi harapan konsumen ketika di dalam toko. Hipotesis yang diajukan adalah:

Contoh dari petunjuk desain (design cue) yang mungkin mempengaruhi harapan konsumen ketika di dalam toko. Hipotesis yang diajukan adalah:

H1a. Pada waktu persepsi konsumen tentang bentuk desain toko menjadi lebih baik, konsumen akan menganggap biaya atas waktu/usaha yang dikeluarkan menjadilebih rendah (-).

Penelitian sebelumnya menawarkan dukungan empiris hubungan yang umum antara lingkungan secara keseluruhan dan pengaruhnya (Babin dan Darden, 1996). Desain toko yang tidak bagus, lay out toko yang membingungkan konsumen dapat menjadi penyebab konsumen merasa harus mengeluarkan biaya psikis/ pikiran. Desain toko yang tidak bagus dapat menjadi penyebab berkurangnya kenyamanan konsumen dan menjadi penyebab merosotnya niat konsumen untuk berbelanja (Spies, Hesse, Loesch, 1997). Maka hipotesis yang kedua adalah:

H1b. Pada wakiu persepsikonsumen tentang bentuk desain toko menjadi lebih baik, konsumen akan menganggap biaya psikis yang dikeluarkan mènjadilebih rendah (-).

Atmosfir toko, lingkungan di dalam toko akan disamakan dengan keyakinan konsumen tentang harga dari harga yang sebenarnya dan dapat digunakan untuk 
merancang harga yang berbeda untuk produkproduk yang tidak begitu jelas perbedaannya. Suasana atmosfir lingkungan toko akan berpengaruh terhadap harapan konsumen tentang harga. Grewal dan Baker (1994) menyatakan bahwa persepsi konsumen akan suasana lingkungan toko yang lebih baik akan meningkatkan penerimaan tingkat harga suatu produk. Dari situasi ini maka hipotesis yang dapat diajukan adalah:

H1c. Pada waktu persepsi konsumen tentang suasana lingkungan toko menjadi lebih baik, konsumen akan menganggap biaya moneter yang dikeluarkan menjadi lebih tinggi(+).

Dari situasi ini maka hipotesis yang dapat diajukan adalah:

H1c. Pada waktu persepsi konsumen tentang suasana lingkungan toko menjadi lebih baik, konsumen akan menganggap biaya moneter yang dikeluarkan menjadi lebih . tinggi (+).

Secara teoritis ada pendapat yang menyatakan bahwa ada hubungan langsung antara desain toko ritel dan persepsi konsumen terhadap kualitas pelayanan secara pribadi dari karyawan toko (Bitner, 1990), seperti yang dilakukan dalam beberapa penelitian empiris. contohnya adalah perbandingan gaya modern dengan gaya tradisional pada beberapa bank cabang, yaitu bahwa konsumen menjumpai karyawan pada bank cabang yang modern lebih memberikan pelayanan yang proaktif daripada karyawan di bank tradisional (Greenland, McGoldrick, 1994). Atmosfir toko dapat mencerminkan tingkat perhatian konsumen terhadap tingkat pelayanan karyawan toko, sehingga hipotesis yang diajukan adalah:

H1d. Pada waktu persepsi konsumen tentang suasana lingkungan toko menjadi lebih baik, konsumen akan menganggap kualitas pelayanan dari karyawan toko menjadi lebih baik(+).

Desain lingkungan toko ritel dapat menyediakan dasar evaluasi yang penting bagi konsumen tentang kualitas 
dalam (Baker, dan Parasuraman, 2002) menyebutkan bahwa beberapa responden menilai merek parfum lebih baik ketika desain toko digambarkan dengan atribut yang bercitra tinggi dengan lantai berkarpet, dan di tempat yang luas daripada apabila parfum itu dirancang letaknya berada pada lantai biasa tanpa karpet, dekat dengan deretan tempat duduk yang sempit yang akan mencerminkan produk itu bercitra rendah. Demikian juga untuk penataan atau display sebuah restoran, bahwa ruangan istirahat yang bersih menjadi faktor penting yang mempengaruhi persepsi konsumen tentang kualitas makanan secara keseluruhan (Buchanan, 1999). Temuan ini mendasari hipotesis berikutnya yakni :

Tanpa karpet, dekat dengan deretan tempat duduk yang sempit yang akan mencerminkan produk itu bercitra rendah. Demikian juga untuk penataan atau display sebuah restoran, bahwa ruangan istirahat yang bersih menjadi faktor penting yang mempengaruhi persepsi konsumen tentang kualitas makanan secara keseluruhan (Buchanan, 1999). Temuan ini mendasari hipotesis berikutnya yakni:

H1e. Pada waktu persepsi konsumen tentang desain toko menjadi lebih baik, konsumen akan menganggap kualitas barang dagangan yang tersedia menjadilebih baik/bagus (+).

Keadaan sosial toko/karyawan toko dinyataan sebagai elemen sosial toko, terlalu banyak karyawan dalam area yang terlalu kecil dapat mempengaruhi persepsi konsumen tentang kepadatan. Penelitian empiris telah menguji hubungan antara karyawan toko dan persepsi konsumen mengenai biaya waktu/usaha dałam penataan ritel (Eroglu dan Machleit, 1990). Pandangan dari riset yang terbatas menyatakan bahwa jumlah tenaga penjual pada suatu lantai mempengaruhi persepsi konsumen akan biaya waktu/usaha yang dikeluarkan. Jumlah tenaga penjual yang berlebih akan menandakan bahwa konsumen akan menyediakan waktu lebih sedikit untuk mencari barang dagangan (merchandise). Hipotesis yang diajukan adalah:

H2a. Pada waktu persepsi konsumen mengenai jumlah karyawan toko menjadi lebih baik, konsumen akan menganggap biaya waktu/usaha yang dikeluarkan menjadi lebih rendah (-). 
Penelitian sebelumnya menyatakan bahwa tenaga penjual memainkan peran penting dalam mempengaruhi niat dan kepuasan konsumen (Grewail dan Sharma, 1991). Sesuai juga untuk komponen teori Barker dari ekologi lingkungan, ketika jumlah orang dalam pelayanan lebih sedikit daripada yang dibutuhkan untuk fungsi pelayanan yang sepantasnya, dikatakan sebagai kondisi kekurangan tenaga penjual (understaffing). Pemahaman tentang kerangka ini menyajikan bahwa jumlah karyawan toko ritel di dalam toko akan mempengaruhi persepsi dan tanggapan konsumen. Demikian juga ketika beberapa tenaga penjual berada di lantai (dengan jumlah relatif untuk kepadatan konsumen yang tidak terlalu), konsumen dapat menjadi frustasi dan terganggu. Hipotesis yang diajukan adalah:

H2b. Pada waktu persepsi konsumen tentang karyawan toko ritel menjadi lebih baik, konsumen akan menganggap biaya psikis menjadilebihrendah (-).

Penelitian sebelumnya menyatakan bahwa tenaga memainkan peran penting dalam mempengaruhi niat dan kepuasan konsumen (Grewal dan Sharma, 1991). Sesuai juga untuk komponen teori Barker dari ekologi lingkungan, ketika jumlah orang dalam pelayanan lebih sedikit daripada yang dibutuhkan untuk fungsi pelayanan yang sepantasnya, dikatakan sebagai kondisi kekurangan tenaga penjual (understaffing). Pemahaman tentang kerangka ini menyajikan bahwa jumlah karyawan toko ritel di dalam toko akan mempengaruhi persepsi dan tanggapan konsumen. Demikian juga ketika beberapa tenaga penjual berada di lantai (dengan jumlah relatif untuk kepadatan konsumen yang tidak terlalu), konsumen dapat menjadi frustasi dan terganggu. Hipotesis yang diajukan adalah:

H2b. Pada waktu persepsi konsumen tentang karyawan toko ritel menjadi lebih baik, konsumen akan menganggap biaya psikis menjadilebih rendah (-).

Kerangka kerja lain yang diajukan oleh Wicker, 1973 dalam (Baker dan Parasuraman, 2002) juga menyarankan bahwa adanya karyawan toko nampaknya akan mempengaruhi persepsi konsumen tentang kualitas 
pelayanan karyawan toko. Jumlah dan penampakan karyawan dalam penataan ritel merupakan tanda-tanda yang nampak dari kualitas pelayanan. Penelitian saat ini juga menyarankan bahwa interaksi antara konsumen dengan karyawan toko mempengaruhi penilaian konsumen tentang kualitas pelayanannya. (Hartline dan Ferrel, 1996). Selanjutnya interaksi yang positif antara konsumen dengan karyawan, seperti pengakuan konsumen ketika mereka sudah sampai ke toko, juga dapat mempengaruhi persepsi kualitas pelayanan karyawan toko. Hipotesis yang diajukan adalah:

H2d. Pada waktu persepsi konsumen tentang karyawan toko menjadi lebih baik, konsumen àkan menganggap kualitas pelayanan karyawan menjadi lebih tinggi $(+)$.

H2d. Pada waktu persepsi konsumen tentang karyawan toko menjadi lebih baik, konsumen akan menganggap kualitas pelayanan karyawan menjadilebih tinggi (+).

Karyawan toko diharapkan dapat memiliki pengaruh yang positif terhadap persepsi kualitas merchandise. Karyawan toko merupakan bagian dari skenario toko secara keseluruhan untuk mendapatkan pengaruh yang positif dari lingkungan toko terhadap persepsi konsumen tentang merchandise (Rao dan Kent B,1989). Seorang tenaga penjual yang mengenakan baju. dengan tidak rapi, tidak menyenangkan, tidak bekerjasama, tidak memuaskan, dan tidak mau bekerjasama akan memberikan pengaruh negatif. Sementara itu seorang karyawan toko yang bersahabat dan berpengetahuan akan berpengaruh positif terhadap persepsi konsumen tentang merchandise. hipotesis yang dapat diajukan adalah:

H2e. Pada waktu persepsi konsumen tentang karyawan toko menjadi lebih baik, konsumen akan menganggap kualitas merchandise menjadi lebih tinggi $(+)$.

\subsubsection{Faktor Keramaian/Kepadatan (Store Music)}

Suara musik di dalam toko dianggap dapat berpengaruh baik terhadap persepsi konsumen tentang waktu tunggu konsumen, dan dapat mengurangi waktu/usaha yang 
dikeluarkan konsumen Selanjutnya hipotesis yang diajukan dalam penelitian ini adalah:

. . . . . . . . $\therefore \quad \therefore \quad . \quad 3$. suara musik dapat mempengaruhi respon secara umum

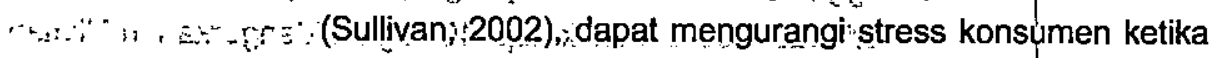

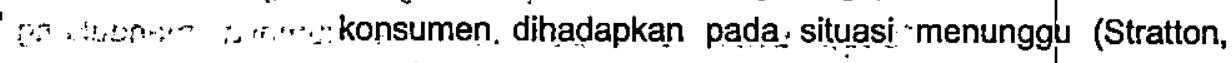
(

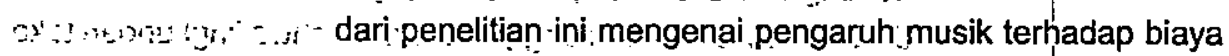
.... psikis. Hipotesis yang diajukan adalah:

Iy

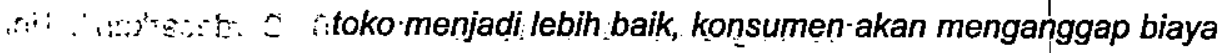
psikis yang dikeluarkan menjadilebih rendah $(-)$.

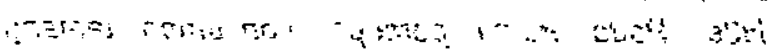

-

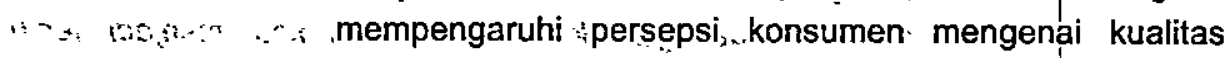
pelayanan karyawan toko. Beberapa, penelitian sebelumnya mencoba mengembangkan pendapat secara konseptual

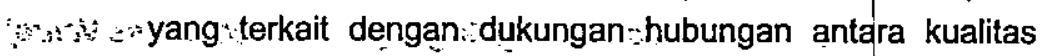
1.: "

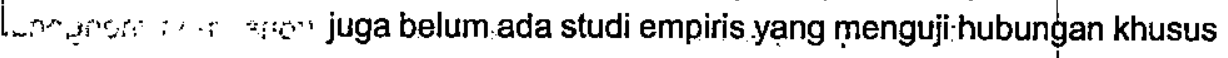
r. 1

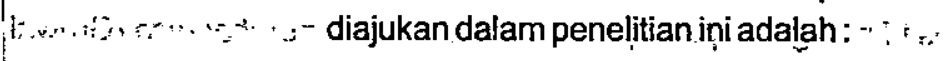

dalam toko menjadi lebih, baik, konsumen akan menganggap

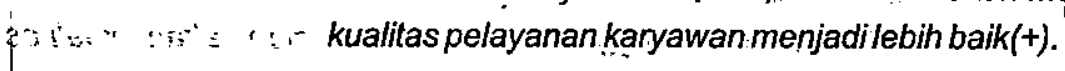
1 $\therefore$.

... Pemilik toko telah membeli lebih mahal (kualitas lebih tinggi) ketika musik klasik yang diperdengarkan di dalam toko daripada ketika musik top 40 lagu didengarkan (Milliman, -1982):' Lebih- jauh 'penelitian sebelumnya mendukung $\because$ hubungan antara adanya musik dengan kualitas merchandise.

: 3... . . . . syang:padat dengan latar belakang musik yang menyejukkan

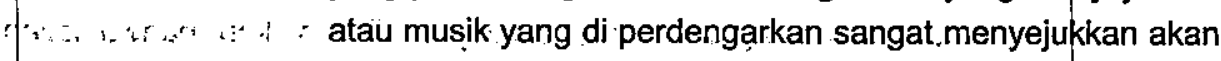

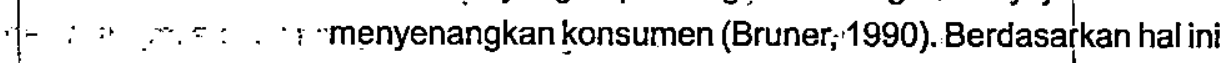
hipotesis yang diajukan adalah: $1 . ; . ;$.

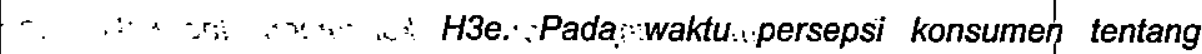
. ", , , , - = adanya musik didalam toko menjadi lebih baik, konsumen 
akan menganggap kualitas merchandise menjadi lebih tinggi( + ).

Pemilik toko telah membeli lebih mahal (kualitas lebih tinggi) ketika musik klasik yang diperdengarkan di dalam toko daripada ketika musik top 40 lagu didengarkan (Milliman, 1982). Lebih jauh penelitian sebelumnya mendukung hubungan antara adanya musik dengan kualitas merchandise. Satu penelitian telah menggambarkan bahwa lingkungan toko yang padat dengan latar belakang musik yang menyejukkan atau musik yang di perdengarkan sangat menyejukkan akan menyenangkan konsumen (Bruner, 1990). Berdasarkan hal ini hipotesis yang diajukan adalah:

H3e. Pada waktu persepsi konsumen tentang adanya musik di dalam toko menjadi lebih baik, konsumen akan menganggap kualitas merchandise menjadi lebih tinggi(+).

\subsubsection{Faktor Nilai Barang Dagangan (Merchandise Value)}

Model yang diajukan dalam penelitian ini menyatakan bahwa perhatian pelanggan toko merupakan fungsi dari nilai merchandise, kualitas pelayanan karyawan, dan persepsi konsumen mengenai biaya-biaya yang dikelurkan selama berbelanja. Penelitian sebelumnya lebih rinci menyarankan adanya suatu hubungan yang positif mengenai persepsi kualitas dan nilai merchandise (Grewal, 1998). Hipotesis terkait dengan hubungan variabel persepsi kualitas dan nilai merchandise adalah:

H4. Semakin tinggi persepsi konsumen akan kualitas merchandise, akan menjadi lebih tinggi juga persepsi konsumen tentang nilai merchandise itu nantinya(+).

Hubungan antara biaya atas pengalaman berbelanja dengan nilai merchandise masih belum banyak diuji. Penelitian sebelumnya menyarankan bahwa konsumen mengeluarkan waktu atau biaya atas usaha selama proses pembelian dan konsumen menempatkan kebutuhan belanja ini sebagai kebutuhan penting atas waktu yang dimilikinya. Lebih jauh disimpulkan bahwa setiap produk memiliki sebuah harga atas waktu yang secara implisit telah termasuk di dalamnya.

H5b. Semakin tinggi persepsi konsumen atas waktu/usaha yang diperlukan untuk berbelanja, maka semakin rendah pula 
persepsikonsumen tentang nilaimerchandise itu $(-)$

H5c. Semakin tinggi persepsi konsumen tentang biaya psikis, maka semakin rendah persepsi konsumen mengenai nilai merchandise(-).

semakin rendah pula persepsi konsumen tentang nilai merchandise itu(-)

H5c. Semakin tinggi persepsi konsumen tentang biaya psikis, maka semakin rendah persepsi konsumen mengenai nilai merchandise(-).

\subsubsection{Faktor Pelanggan Toko (Store Patronage Intentions)}

Meskipun riset telah konsisten menunjukkan bahwa pengaruh kualitas produk terhadap perilaku secara luas dimediasi oleh adanya persepsi konsumen terhadap nilai merchandise, penelitian sebelumnya telah menemukan adanya hubungan langsung antara kualitas pelayanan dengan maksud/perhatian pelanggan toko (Berry dan Parasuraman, 1996), sehingga hipotesis yang diajukan adalah:

H6. Semakin tinggi persepsi konsumen tentang kualitas pelayanan karyawan, maka akan semakin tinggi pula maksud/perhatian pelanggan toko(+).

Penerimaan nilai produk adalah sesuai dengan tujuan utama dari perhatian dan perilaku pelanggan. Penelitian ini memfokuskan pada konsep niat/perhatian pelanggan toko, termasuk di dalamnya adalah maksud konsumen ke toko dan merekomendasikannya kepada konsumen lain. Dengan demikian harapannya adalah ada hubungan positif antara nilai merchandise dengan niat/perhatian pelanggan toko. Sehingga hipotesis yang dapat diajukan adalah:

H7. Semakin tinggi persepsi konsumen tentang nilai merchandise maka akan semakin tinggi pula niat/maksud/perhatian pelanggan toko(+).

\section{METODE PENELITIAN}

Survei lapangan dilakukan untuk mendapatkan data riset. Responden yang dibidik adalah konsumen yang sedang melakukan pembelian, masuk ke dalam toko ritel berjalan-jalan kurang lebih lima menit menikmati suasana/kondisi toko kemudian berbelanja atau konsumen yang sudah selesai dari berbelanja. Jumlah responden yang diperlukan dalam penelitian ini 
sebanyak 300 responden, dengan mengacu pada penelitian sebelumnya dengan 297 orang. Lima orang tenaga lapangan menyebar kuesioner ini pada empat hypermarket besar, dua Mall besar serta beberapa supermarket atau swalayan di Yogyakarta. Kuesioner yang disebar kurang lebih 300 kuesioner, sementara itu jumlah kuesioner yang layak untuk diolah lebih lanjut hanya berjumlah 190 kuesioner. Kuesioner didesain dengan model pertanyaan terbuka dan tertutup, Skala Likert 5 poin penilaian. Pilihan alternatif jawaban yang disediakan adalah sangat setuju (skor 5), setuju (skor 4), netral atau tidak tahu (skor 3), tidak setuju (skor 2) dan sangat tidak setuju (skor 1).

Sampel ditentukan dengan menggunakan nonprobabilistic sampling, di mana setiap elemen dalam populasi tidak memiliki probabilitas yang sama untuk dipilih menjadi sampel atau pemilihan anggota sampel dilakukan dengan tidak acak dan bersifat subyektif (Sekaran, 1992, h.235-244; Cooper dan Emory, 1995, h.227-230). Teknik penentuan sampel nonprobabilitas yang digunakan adalah 1) convenience sampling, yakni pengambilan sampel berdasarkan pada ketersediaan dan kemudahan untuk mendapatkan sampel. 2) Judgment sampling digunakan untuk memilih responden dengan kriteria tertentu. Kriteria responden adalah konsumen yang sedang berbelanja di sebuah toko ritel, atau menjadi pelanggan hypermarket seperti Alfa, Indogrosir, Makro, Carefour. Termasuk juga responden yang menjadi pelanggan supermarket, atau swalayan besar seperti Hero, Mirota, Progo, Pamella, dan WS yang merupakan supermarket besar di Daerah Istimewa Yogyakarta. Kuesioner dan tes skala diberikan langsung kepada responden dan diambil segera setelah ditisi oleh responden.

\subsection{Variabel Penelitian}

Penelitian ini merupakan penelitian eksplorasi yang mengungkapkan pendapat dan persepsi konsumen terhadap suasana atau keadaan toko yang didesain oleh peritel. Variabel-variabel yang digunakan terdiri dari variabel lingkungan toko (store environment), variabel kriteria pilihan toko (store choice criteria) dan variabel perhatian pelanggan toko (store patronage intentions). Variabel lingkungan toko terdiri dari faktor sosial (social factor), faktor desain (design factor) dan keadaan toko (ambient factor). Variabel kriteria pilihan toko (store choice criteria) dilihat dari persepsi perhatian pelanggan toko (store patronage intentions). Variabel lingkungan toko terdiri dari faktor sosial (social factor), faktor desain (design factor) dan keadaan toko (ambient factor).Variabel kriteria pilihan toko (store choice criteria) dilihat dari persepsi konsumen terhadap pelayanan pribadi karyawan (interpersonal service quality perception), kualitas merchandise (merchandise quality perceptions), 
harga dalam satuan moneter (monetary price perceptions), biaya waktu atau usaha (time/ effort cost perceptions), dan biaya psikis (psychic cost perceptions).

Masing-masing variabel dirinci kedalam beberapa pertanyaan yang diajukan kepada responden, dengan pilihan alternatif jawaban yang disediakan adalah sangat setuju (skor 5), setuju (skor 4), netral atau tidak tahu (skor 3), tidak setuju (skor 2) dan sangat tidak setuju (skor 1).

\subsubsection{Persepsi Konsumen Mengenai Suara Musik (Music Cue Perceptions)}

Persepsi konsumen ketika masuk ke dalam sebuah toko yang di dalamnya didengarkan suara alunan musik memiliki pengaruh negatif terhadap biaya psikis. Persepsi konsumen akan hal ini mempunyai hubungan dengan biaya dari pengalaman berbelanja konsumen yang pada dasarnya sama yaitu persepsi terhadap adanya musik menjadi lebih baik (Milliman, Ronald. E, 1982). Musik memiliki pengaruh yang efektif terhadap konsumen (Bruner, 1990), terutama mempengaruhi kognisi konsumen. Musik berpengaruh positif terhadap kognisi konsumen pada saat konsumen dihadapkan pada situasi menunggu (Stratton, 1992). Konsumen mempersepsikan musik dapat memperpendek waktu tunggu di dalam toko (Sullivan, Malcolm, 2002).

\subsubsection{Persepsi Konsumen Mengenai Harga (Monetary Price Perceptions)}

Persepsi konsumen terhadap desain rancangan layout toko berpengaruh positif terhadap anggapan konsumen tentang harga (moneter). Melihat desain toko yang bagus menjadikan konsumen akan beranggapan bahwa harga yang diberlakukan di toko tersebut tinggi. Secara keseluruhan konsumen akan menggunakan pengetahuannya tentang lingkungan toko sebagai kerangka yang diketahuinya untuk membuat prediksi mengenai harga (Parsons dan W.Bailey,1972). Persepsi konsumen yang lebih tinggi mengenai citra toko/lingkungan toko (desain, karyawan dan musik) akan menjadikan persepsi konsumen mengenai harga yang berlaku di toko tersebut juga tinggi. Secara keseluruhan konsumen akan menggunakan pengetahuannya tentang lingkurigan toko sebagai kerangka yang diketahuinya untuk membuat prediksi mengenai harga (Parsons dan W.Bailey, 1972). Persepsi konsumen yang lebih tinggi mengenai citra toko/lingkungan toko (desain, 
karyawan dan musik) akan menjadikan persepsi konsumen mengenai harga yang berlaku di toko tersebut juga tinggi.

\subsubsection{Kualitas Barang Dagangan (Merchandise quality)}

Persepsi konsumen terhadap desain toko berfungsi sebagai anteseden persepsi konsumen terhadap kualitas barang dagangan (merchandise). Desain toko yang bagus, rapi dengan diringi alunan musik akan menjadikan konsumen beranggapan bahwa kualitas barang dagangan yang disediakan toko tersebut bagus (Rao dan Kent B,1989). Konsumen mengevaluasi kualitas pelayanan seperti pada saat ia mengevaluasi kualitas barang dagangan (Zeithaml, 1988).

\subsubsection{Interpersonal service quality}

Satu indikator pelayanan yang digunakan adalah kualitas pelayanan karyawan (Interpersonal service quality) yang bersifat pribadi/khusus/unique. Indikator .pelayanan yang lain seperti intangible, inseparibility, variability dan perishability tidak ikut dipertimbangkan dalam penelitian ini. Konsumen akan melihat desain/ layout toko dan keadaan karyawan untuk memperkirakan persepsinya terhadap kualitas pelayanan interpersonal. Termasuk didalam bentuk kualitas pelayanan karyawan adalah pemberian pelayanan yang baik, pelayanan barang dagangan dengan cepat dan perhatian karyawan toko.

\subsubsection{Merchandise Value}

Nilai barang dagangan merupakan fungsi dari biaya waktu/usaha, biaya psikis, kualitas merchandise dan harga (moneter). Woodruf (1997) menyarankan bahwa nilai adalah suatu konstruk dinamis yang memiliki makna dan mengevaluasi kriteria yang dapat berubah layaknya seperti seorang konsumen yang mendapatkan pengalaman. Nilai dapat berubah seperti perubahan . eksposure yang diterima oleh konsumen. Seorang konsumen yang mendapatkan pengalaman. Nilai dapat berubah seperti perubahan eksposure yang diterima oleh konsumen.

\subsubsection{Perhatian Pelanggan Toko (Store Patronage Intentions)}

Variabel yang secara signifikan mempengaruhi perhatian pelanggan toko adalah kualitas pelayanan karyawan, nilai merchandise, biaya atas waktu/usaha, dan biaya psikis. Konsumen 
menganggap bahwa nilai merchandise dan biaya psikis adalah dua variabel yang menjadi faktor penentu utama dari perhatian pelanggan toko (store patronage intentions).

\subsection{Pengujian Kualitas Data}

Uji validitas butir pertanyaan dilakukan dengan bantuan program SPSS for Windows Release 13.0. mengunakan korelasi Product Moment dari Pearson (Santoso, 2000, h.221). Uji Pearson digunakan untuk mengkorelasikan skor per item dengan skor totalnya. Berdasarkan pengujian tersebut setiap butir berkorelasi positif terhadap skor total dengan signifikansi level 0,01. Hasil pengujian korelasi Product Moment Pearson sbb:

Tabel 3.1

HASIL UJI VALIDITAS

\begin{tabular}{|c|c|c|c|}
\hline Variabel & Korelasi Pearson & Signifikansi & Ketërangan \\
\hline Desain1 & 0,672 & 0,01 & Valid \\
\hline Desain2 & 0,697 & 0,01 & Vạlid \\
\hline Desain3 & $0,661^{-}$ & 0,01 & Valid \\
\hline Desain4 & 0,792 & 0,01 & Valid \\
\hline Desain5 & 0,741 & $\overline{0,01}$ & Valid \\
\hline Pram1(pramuniaga1) & 0,602 & 0,01 & Valid \\
\hline Pram2 & 0,859 & 0,01 & Valid \\
\hline Pram3 & $0, \overline{803}$ & 0,01 & Valid \\
\hline Pram4 & 0,830 & 0,01 & Valid \\
\hline Musik1 & 0,848 & 0,01 & Valid \\
\hline Musik2 & 0,812 & 0,01 & Valid \\
\hline Musik3 & $0, \overline{794}$ & 0,01 & Valid \\
\hline Musik4 & 0,732 & 0,01 & Valid \\
\hline Waktu1 & $0, \overline{368}$ & 0,01 & Valid \\
\hline Waktu2 & 0,808 & 0,01 & Valid \\
\hline Waktu3 & 0,783 & 0,01 & Valid \\
\hline Waktu4 & 0,769 & 0,01 & Valid \\
\hline Psikis1 & 0,838 & 0,01 & Valid \\
\hline Psikis2 & 0,889 & 0,01 & Valid \\
\hline Psikis3 & 0,892 & 0,01 & Valid \\
\hline Psikis4 & 0,875 & $0, \overline{01}$ & Valid \\
\hline Biaya1 & 0,893 & 0,01 & Valid \\
\hline Biaya2 & 0,906 & 0,01 & Vạlid \\
\hline Biaya3 & 0,927 & 0,01 & Valid \\
\hline Pelayn1(pelayanan1) & 0,720 & 0,01 & Valid \\
\hline Pelayn2 & 0,754 & 0,01 & Valid \\
\hline Pelayn3 & 0,854 & 0,01 & Vạlid \\
\hline Pelayn4 & 0,806 & 0,01 & Valid \\
\hline
\end{tabular}




\begin{tabular}{|c|c|c|c|}
\hline Pelayn5 & 0,785 & 0,01 & Valid \\
\hline Kualits1 & 0,730 & $\because 0,01$ & Valid \\
\hline Kualits2 & 0,784 & 0,01 & Valid \\
\hline Kualits3 & 0,779 & 0,01 & Valid \\
\hline Kualits4 & $0,761 \therefore:$ & $-i, 0,0, \ldots$ & $\because$ Valid \\
\hline 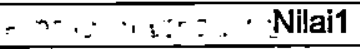 & $\therefore \ldots 0,804, \ldots=$ & 0,01 & Valid \\
\hline $\begin{array}{rrrr}r & \therefore & \prime\end{array}$ & 0,714 & 0,01 & - : Valid \\
\hline$\therefore . . . \quad$ Nilai3 & $0,759, \ldots$ & 0,01 & Valid \\
\hline - Nilai4 & 0,771 & 0,01 & Valid \\
\hline Ketert1 & 0,726 & 0,01 & Valid \\
\hline Ketert2 & 0,750 & 0,01 & ${ }^{2}$ Valid \\
\hline Ketert3 & ' $\quad 0,836$ & $\because r=0,01=$ & -Valid \\
\hline Ketert4 & 0,817 & $0,01: \ldots$ & $\therefore$ - Valid \\
\hline
\end{tabular}

Hasil uji validitas dengan $N$ :data sebanyak 190 dengan 41 butir pertanyaan taraf signifikańsi $1 \%$ atau $(0,01)$ diperoleh angka $r$ tabe.

\begin{tabular}{|c|c|c|c|}
\hline$\therefore \ldots$ Psikis4 & $\therefore-0,875$ & $\because 0,01 \cdots$ & $=\because$ Valid \\
\hline Biaya1. & 0,893 & 0,01 & Valid $^{-} \ldots$ \\
\hline Biaya2 & $\overline{0}, 906$ & 0,01 & Valid $^{-} \therefore$ \\
\hline . r Biaya3 & $0 ; 927 \quad \ddots$ & 0,01 & Valịd. \\
\hline Pelayn1(pelayananin & $0,720 \cdots$ & $0,01^{-}$ & Valid $^{-}$- \\
\hline Pelayn2; & $0,754^{--} \vdots$ & $0,01^{--}$ & Valid :- - \\
\hline Pelayn3. & 0,854 & 0,01 . & Valid \\
\hline Pelaynin: & 0,806 & 0,01 & $\therefore$ Valid \\
\hline Pelayri5 & $0,785 \quad \vdots$ & 0,01 & $\therefore \quad$ Valid \\
\hline : Kualits1 & 0,730 & 0,01 & - Valid \\
\hline Kualits2 & $0,784 \ldots$ & $0,01{ }^{-}:$ & Valid \\
\hline Kúalits3 & 0,779 & 0,01 . & Valid \\
\hline Kualits4 & $0,761, \cdot$ & $0,01, \ldots, i$ & Valid \\
\hline Nilai1 & $0,804 \ldots$ & $0,01 \ldots$ & Valid \\
\hline Nilai2 & $0,714-\because \vdots$ & 0,01 & Valid "' \\
\hline Nilai3 & 0,759 & 0,01 & Valid \\
\hline Nilai4 & 0,771 & $\overline{0,01}$ & Valid \\
\hline Këtert1 & 0,726 & 0,01 & Valid \\
\hline Ketert2 & 0,750 & 0,01 & Valid \\
\hline Ketert3 & 0,836 & 0,01 & Valid \\
\hline Ketert4 & 0,817 & $\overline{0,01}$ & Valid \\
\hline
\end{tabular}

Hasil uji validitas dengan $N$ data sebanyak 190 dengan 41 butir pertanyaan taraf signifikansi $1 \%$ atau $(0,01)$ dipèroleh angka r tabel 0,181 . Dengan demikian butir-butir pertanyaan yang memiliki $r$ hitung $>r$ tabel adalah valid ataú sahih. Sedangkan butir pertanyaan yang memiliki $r$ hitung < r tabel aḱan gugur dan dikeluarkan dari analisa data berikutnya. Diketahui bahwa hampir seluruh butir pertanyaan sahih atau valid, dengan nilai korelasi pearson berkisar antara 0,3 sampai dengan 0,9 , signifikansi 
pada level 0,01 . Sementara itu reliabilitas data diukur menggunakan Koefisien Cronbach Alpha. Instrumen penelitian dikatakan reliable apabila pengujian tersebut menunjukkan alpha lebih dari 0,7 (Sekaran, 1992, h.287-288). Nilai hasil reliabilitas data penelitian diperoleh sebagai berikut:

Tabel 3.2.

Hasi] Uji Reliabilitas

\begin{tabular}{|c|c|c|c|}
\hline Variabel & Nitem perty. & \multicolumn{1}{|l|}{$\begin{array}{l}\text { Koef. Cronbach } \\
\text { Alpha }\end{array}$} & Keteraingan \\
\hline Desain & 5 & 0,7581 & Reliabe! \\
\hline Pram (pramuniaga) & 4 & 0,7819 & Reliabel \\
\hline Musik & 4 & 0,8077 & Reliabel \\
\hline Waktu & 4 & 0,6539 & Reliabel \\
\hline Psikis & 4 & 0,8952 & Reliabel \\
\hline Biaya & 3 & 0,8947 & Reliabel \\
\hline Pelayn (pelayanan) & 5 & 0,8426 & Reliabel \\
\hline Kualits (kualitas brg) & 4 & 0,7585 & Reliabel \\
\hline Nilai (nilai barang) & 4 & 0,7585 & Reliabel \\
\hline Ketert (ketertarikan) & 4 & 0,7887 & Reliabel \\
\hline Total item pertanyaan & 41 & & \\
\hline Sumber: Reliability Analysis & \multicolumn{3}{|c|}{} \\
\hline Biaya & 3 & 0,8947 & Reliabel \\
\hline Pelayn (pelayanan) & 5 & 0,8426 & Reliabel \\
\hline Kualits (kualitas brg) & 4 & 0,7585 & Reliabel \\
\hline Nilai (nilai barang) & 4 & 0,7585 & Reliabel \\
\hline Ketert (ketertarikan) & 4 & 0,7887 & Reliabel \\
\hline Total item pertanyaan & 41 & & \\
\hline
\end{tabular}

Hasil uji reliabel menggambarkan bahwa variabel desain reliabel di tingkat 0,7581 , variabel pramuniaga reliabel di tingkat 0,7819 , variabel musik reliabel di tingkat 0,8077 , variabel waktu reliabel di tingkat 0.6539 , variabel psikis reliabel di tingkat 0,8952 , variable biaya reliable di 0,8947 , variable pelayanan reliabel pada 0,8426 , variabel kualitas reliabel di tingkat 0,7585 , variabel nilai reliabel di tingkat 0,7585 , dan variabel ketertarikan pelanggan reliabel pada 0,7887.

Tahap berikutnya adalah membentuk semua item pertanyaan yang ada menggunakan confirmatory factor analysis (CFA). Analisis faktor ini digunakan untuk mengidentifikasi pola pemeringkatan yang didasarkan pada bagaimana setiap statemen yang diurutkan berkorelasi dengan yang lain dan mengelompokkan statemen-statemen untuk membentuk faktor-faktor baru.

\subsection{Confirmatory Factor Analysis (CFA)}

Analisis faktor ditujukan untuk mengkonfirmasi butir pertanyaan 
menjadi beberapa faktor. Hasil ekstraksi faktor dengan metode Varimax Rotation dengan Kaiser Normalization menghasilkan 10 komponen atau 10 faktor yang dapat digunakan atau dipertahankan. Hasil rotasi menunjukkan komponen 1 memiliki varians $8,811 \%$ dari varians total. Komponen kedua memiliki varians $8,301 \%$ dari varians total, sehingga dari kedua komponen tersebut mampu menjelaskan $17,112 \%$ keragaman keseluruhan variabel. Kedua komponen tersebut memiliki nilai eigenvalue di atas 1 yaitu 23,819 dan 10,842 . Komponen ketiga dan seterusnya sampai dengan komponen yang kesepuluh memiliki varians senilai $5,940 \%$, sehingga dari kesepuluh komponen yang terbentuk telah dapat menjelaskan $73,013 \%$ dari keseluruhan variabel penelitian.

Tabel 3.3. menunjukkan bahwa hasil besaran factor loading dari masingmasing variabel yang bernilai di atas 0,4 . Terbentuk sepuluh faktor yang dapat dikonfirmasi oleh confirmatory factor analysis. Faktor itu secara berurutan adalah faktor 1 merupakan variabel pelayanan, faktor 2 adalah variabel psikis, faktor 3 merupakan variabel nilai, faktor 4 mewakili variabel desain, faktor 5 adalah faktor biaya, faktor 6 mewakili variabel musik, faktor 7 adalah faktor pramuniaga, faktor 8 adalah variabel ketertarikan pelanggan, faktor 9 mewakili variabel waktu dan faktor 10 mewakili variabel kualitas. Kesepuluh variabel tersebut mewakili $73,013 \%$ dari keseluruhan variabel yang ada. Dengan demikiaṇ faktor yang terbentuk dapat dikatakan telah mewakili seluruh variabel yang diteliti.

Hasil uji komunalitas (ukuran \% dari variasi variabel yang dijelaskan oleh faktor-faktor) menunjukkan adanya nilai komunalitas yang tinggi $(>0,50)$ pada semua butir. Dengan demikian dapat dikatakan secara keseluruhan ada persamaan pada masing-masing variabel yang mewakili 41 butir pertanyaan dan dianggap cukup dapat menjelaskan kedelapan komponen atau kedelapan faktor yang diperoleh (latent factor). Dua faktor dalam AMOS tidak periu digambar karena kedua faktor tersebut sama-sama merupakan factor endogen yang saling berkorelasi. 
Tabel 3.3.

Faktor loading dari Analisis Faktor 41 Butir Pertanyaan

\begin{tabular}{|c|c|c|c|c|c|c|c|c|c|c|}
\hline $\begin{array}{l}\text { Var.n luem } \\
\text { pertany }\end{array}$ & Faktort & Faktor & Faktor3 & Faktor 4 & Falctors & Faktorb & Faktor? & Faktors & Falctorg & $\begin{array}{c}\text { Faktor } \\
0\end{array}$ \\
\hline $\begin{array}{l}\text { Vartabel } \\
\text { Polayanan }\end{array}$ & Felitor & & & & & & & & & \\
\hline Pelogra & 0.77 & & & & & & & & & \\
\hline Pclisynd & 0,765 & & & & & & & & & \\
\hline Pelayns & 0,738 & & & & & & & & & \\
\hline Pelnyn 2 & 0,703 & & & & & & & & & \\
\hline Pelayn! & 0,622 & & & & & & & & & \\
\hline V.Psikís & & Faltor & & & & & & & & \\
\hline Psikid3 & & 0,875 & & & & & & & & \\
\hline Psijis 2 & & 0,870 & & & & & & & 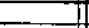 & \\
\hline Poinis4 & & 0,857 & & & & & & & & \\
\hline Psikial & & 0,849 & & & & & & & & \\
\hline V.NIESI & & & Faktor'3 & & & & & & & \\
\hline Nilail & & & 0.719 & & & & & & & \\
\hline Nilait & & & 0,718 & & & & & & & \\
\hline Niłai3 & & & 0,613 & & & & & & & \\
\hline $\mathrm{X}_{\mathrm{i} I 3 i 2}$ & & & 0,590 & & & & & & i & \\
\hline Variaboldosain & & & & Falutor4 & & & & & & \\
\hline Desainl & & & & 0.734 & & & & & & \\
\hline Desain2 & & & & 0.729 & & & & & $\therefore$ & \\
\hline Desain 4 & & & & 0,728 & & & & & & \\
\hline Dessins & & & & 0,591 & & & & & & \\
\hline Desain 3 & & & & 0,530 & & & & & & \\
\hline VarlabolBlaya & & & & & Faktors & & & & & \\
\hline Bioyaz & & & & & 0,894 & & & & & \\
\hline Biayn2 & & & & & 0,878 & & & & & \\
\hline Biayal & & & & & $0,83 x$ & & & & & \\
\hline VariabelMusik & & & & & & Faltor & & & & \\
\hline Musik] & & & & & & 0,827 & & & & \\
\hline Musik2 & & & & & & 0,762 & & & & \\
\hline Musik4 & & & & & & 0,697 & & & & \\
\hline Mysik3 & & & & & & 0.658 & & & & \\
\hline Yar. Pramumlaga & & & & & & & Fentor? & & & \\
\hline Pram4 & & & & & & & 0,764 & & & \\
\hline Prant2 & & & & & & & 0,763 & & & \\
\hline Pram3 & & & & & & & 0,722 & & & 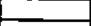 \\
\hline Praml & & & & & & & 0,500 & & & \\
\hline $\begin{array}{c}\text { V. Katertarikan } \\
\text { pel. }\end{array}$ & & & & & & & & $\begin{array}{c}\text { Fantor } \\
\text { B }\end{array}$ & & 1 \\
\hline Keter3 & & & & & & & & 0.774 & & I \\
\hline Ketcrt4 & & & & & & & & 0.727 & & $i$ \\
\hline Karert & & & & & & & & $0, \overline{662}$ & & 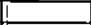 \\
\hline Kater2 & & & & & & & & 0,601 & & 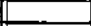 \\
\hline Variabel Waktu & & & & & & & & & Faktorg & 1 \\
\hline Waktu? & & & & & & & & & 0,798 & $t$ \\
\hline Wokren? & & & & & & & & & 0,783 & I \\
\hline Waktud & & & & & & & & & $0,75 B$ & \\
\hline $\begin{array}{l}\text { Varlabel } \\
\text { Kualitas }\end{array}$ & & & & & & & & & & \begin{tabular}{|c|}
$\begin{array}{c}\text { Faktory } \\
0\end{array}$ \\
\end{tabular} \\
\hline Rualits I & & & & & & & & & & 0,606 \\
\hline Kualitis? & & & & & & & & & & 0,599 \\
\hline Kualias 3 & & & & & & & & & & 0,529 \\
\hline Kualitst & & & & & & & & & & 0,485 \\
\hline Waktol & & & & & & & & & & $0, \overline{428}$ \\
\hline
\end{tabular}

Sumber:lampiran Confinnatory Factor Analysis

\section{TEMUAN DAN PEMBAHASAN}

\subsection{Karakteristik Responden}

Sebanyak 190 responden terjaring dalam penelitian ini, terdiri dari 74 responden wanita atau sebanyak $39 \%$, dan 116 responden laki-laki atau sebanyak $61 \%$ dari total responden. Sebanyak 62 responden berusia dibawah 21 tahun, 84 responden berusia $21-25$ tahun, sebanyak 19 responden berusia 26 - 30 tahun, 10 responden berusia $31-35$ tahun, dan sisanya 15 responden berusia di atas 35 tahun. Sebagian besar responden berpendidikan di perguruan tinggi yakni sebanyak 132 responden, sedangkan 44 responden berpendidikan SMU atau sederajat. 
Sebanyak 115 responden adalah berstatus pelajar, 48 responden adalah pegawai swasta dan 17 responden merupakan ibu rumah tangga.

\subsection{Estimasi SEM atau estimasi hasil AMOS}

Estimasi SEM dilakukan bertahap, diawali dengan estimasi Measurement Model dengan teknik Confirmatory Factor Analysis (CFA) kemudian dilanjutkan dengan estimasi Full Structural Equation Model (FSEM). CFA ditujukan untuk mengestimasi measurement model, menguji undimensionalitas

dari konstruk-konstruk eksogen dan konstruk-konstruk endogen, yang nantinya akan mengkonfirmasi apakah variabel yang diamati dapat mencerminkan faktor yang dianalisis. FSEM digunakan untuk menguji model kausalitas yang telah dinyatakan sebelumnya dalam berbagai hubungan sebab akibat (causalmodel).

\section{Evaluasi Full Model Structural Equation Model}

Hasil pengolahan AMOS menunjukkan dua uji dasar yaitu uji kesesuaian model (Goodness of fit Test) dan uji signifikansi kausalitas melalui uji koefisien regresi. Uji kesesuaian model dalam SEM ini ditujukan untuk melihat kesesuaian model. Hipotesa kesesuaian yang diajukan adalah sebagai berikut:

HO :tidak terdapat perbedaan antara matriks kovarians sampel dengan matriks kovarians populasi yang diestimasi

$\mathrm{Ha}$ : terdapat perbedaan antara matriks kovarians sampel dengan matriks kovarians populasi yang diestimasi.

Hasil pengolahan AMOS menunjukkan tingkat signifikansi untuk uji hipotesis perbedaan adalah $\times 2=9,878$ dengan degree of freedom (df) 7 dan probability level sebesar 0,196 , hal ini menunjukkan hipotesa nol tidak dapat ditolak, oleh karena itu kita menerima hipotesis nol yakni tidak terdapat perbedaan antara matriks kovarians sampel dengan matriks kovarians populasi yang diestimasi.

Uji terhadap hipotesis model menunjukkan bahwa model ini sesuai dengan data atau fit terhadap data yang tersedia (lihat tabel 3.4.) dari tingkat signifikansi terhadap chi square model ini sebesar 0,196 . Indeks GFI sebesar 0,987; AGFI sebesar 0,935 ; TLI sebesar 0,971 ; CFI senilai 0,993 serta RMSEA senilai 0,047 memberikan konfirmasi bahwa nilainilai tersebut berada dalam rentang nilai yang diharapkan dan model ini dapat diterima. 
Tabel 3.4.

Goodness of fit Indices

\begin{tabular}{|c|c|c|c|}
\hline Goodness of fit index & Cut off value & Hasil model & Ket. \\
\hline X2- chi square & $\begin{array}{c}\text { Diharapkan } \\
\text { kecil }\end{array}$ & $9,8 \overline{78}$ & - \\
\hline Degree of freedom / df & & 7. & - \\
\hline $\mathrm{X} 2$ significance probability & 0,05 & 0,196 & Baik \\
\hline RMSEA & 0,08 & 0,047 & Baik \\
\hline GFI & 0,09 & 0,987 & Baik \\
\hline AGFI & 0,09 & 0,935 & Baik \\
\hline $\mathrm{CMIN} / \mathrm{DF}$ & 2,00 & $1,41]$ & Baik \\
\hline TLI & 0,90 & 0,971 & Baik \\
\hline CFI & 0,90 & 0,993 & Baik \\
\hline
\end{tabular}

Uji kausalitas atau regression test adalah menguji hipotesa mengenai kausalitas yang dikembangkan dalam model. Tabel berikut menyajikan nilai-nilai koefisien regresi dan $t$ hitung (kolom c.r.- critical ratio) dari masing-masing hipotesis. Diketahui bahwa dari seluruh hipotesis yang diajukan dalam model penelitian ini terdapat lima belas hipotesis signifikan pada tingkat alpha tertentu, sedangkan tujuh hipotesis tidak signifikan. Signifikansi nilai criterion ratio dapat diterima apabila nilai criterion ratio ( $\mathrm{t}$ hitung) berada di atas nilai tabel two tailed pada tingkat alpha tertentu.

Tabel 3.5.

Estimasi Parameter Regresi

Regression Weights: (Group number 1- Default model).

\begin{tabular}{|c|c|c|c|c|c|c|c|c|c|}
\hline & Estimate & S.E. & C.R. & $\mathbf{P}$ & Label & $\mathrm{Ha}$ & Ket $\mathrm{Ha}$ & $\begin{array}{c}\text { Alpha } \\
\text { () }\end{array}$ & No \\
\hline $\mid$ M VAL <--DESIGN & 199 & 061 & 3,283 & ,001 & + & Hlc & diterima & 0,02 & Sig \\
\hline SERV <--DESIGN & ,019 & 077 & 251 &, 802 & + & Hld & Ditolak & - & 2 \\
\hline SERV <-- SEP & ,380 &, 076 & 5,035 & $* * *$ & + & $\mathrm{H} 2 \mathrm{~d}$ & diterima & 0,01 & Sig \\
\hline QUA $<-$ SERV & 296 & ,056 & 5,324 & **** & + & $\begin{array}{l}\text { Corr } \\
\text { path }\end{array}$ & & & \\
\hline QUA «- SEP &,- 007 & ,061 &,- 107 & ,915 & + & $\mathrm{H} 2 \mathrm{e}$ & Ditolak & - & 4 \\
\hline QUA <--DESIGN & ,156 &, 059 & 2,650 &, 008 & + & Hle & diterima & 0,02 & Sig \\
\hline M QUA $<-$ MUSIC &, 081 & ,048 & 1,710 &, 087 & + & $\mathrm{H} 3 \mathrm{e}$ & diterima & 0,20 & Sig \\
\hline COST $<-\quad$ SEP & 039 &, 114 & 346 &, 729 & + & $\begin{array}{l}\mathrm{H} 2 \mathrm{a} ; \\
\mathrm{H} 2 \mathrm{~b}\end{array}$ & Ditolak & - & 7,8 \\
\hline COST <--DESIGN &,- 016 & ,117 &,- 138 &, 890 & - & $\begin{array}{l}\text { Hla, } \\
\text { Hlb }\end{array}$ & Ditolak & - & 9,10 \\
\hline COST $\prec$ MUSIC &,- 054 &, 093 &,- 584 & ,559 & - & $\begin{array}{l}\text { H3a; } \\
\text { H3b }\end{array}$ & Ditolak & - & 11,12 \\
\hline $\operatorname{COST}<-$ QUA &,- 210 & 133 & $-1,575$ & ,115 & - & $\begin{array}{l}\text { Corr } \\
\text { path }\end{array}$ & & & - \\
\hline VAL $<--$ QUA &, 580 &, 059 & 9,772 & $* * *$ & + & $\mathrm{H} 4$ & diterima & 0,01 & Sig 13 \\
\hline VAL $<-$ COST &,- 179 &, 035 & $\begin{array}{r}-5,041 \\
-\ldots \\
-\end{array}$ & $\cdots$ & - & HSb;HSc & diterima & 0,01 & Sig 14,15 \\
\hline & & & & & 4 & 4 & $\therefore$ & & 1225 \\
\hline
\end{tabular}


Khusniyah Purwani : Persepsi Konsumen Mengenai Suasana

\begin{tabular}{|c|c|c|c|c|c|c|c|c|c|c|}
\hline Int & $<-$ MUSIC | & 134 &, 048 & 2,766 &, 006 & + & H3d & diterima 0,02 & Sig & 16 \\
\hline Int & $<$ MVAL & 306 &, 075 & 4,088 & $* * *$ & + & H7 & diterima 0,01 & Sig & 17 \\
\hline int & $<--$ SQUA & 135 & ,089 & 1,514 & ,130 & + & H6 & diterima 0,20 & Sig & 18 \\
\hline int & $<-$ eтror8 & ,418 & ,022 & 19,442 & $* * *$ & - & $\begin{array}{l}\text { Corr } \\
\text { path }\end{array}$ & & & - \\
\hline int & $<$ SERV &, 059 & ,059 & ,998 &, 318 & + & $\mathrm{H} 2 \mathrm{a}$ & Ditolak & & 19 \\
\hline int & $<--$ DESIGN & , 184 & .059 & 3,112 &, 002 & + & Hld & Diterima 0,02 & Sig & 20 \\
\hline & & Estimate & S.E. & C.R. & $\mathbf{P}$ & Label & $\mathrm{Ha}$ & $\begin{array}{r}\text { Ket } \mathrm{Ha} \text { Alpha } \\
\text { ( ) }\end{array}$ & & No \\
\hline SEP & $<-$ MUSIC & ,363 &, 059 & 6,143 & $* * *$ & + & $\begin{array}{l}\text { Corr } \\
\text { path }\end{array}$ & & & - \\
\hline MUSI & $<-$ DESIGN & 194 & 106 & 1,825 & ,068 & + & $\begin{array}{l}\text { Corr } \\
\text { path }\end{array}$ & & & \\
\hline DESIG & $N<-\quad$ SEP & ,368 &, 064 & 5,741 & $* * *$ & + & $\begin{array}{l}\text { Corr } \\
\text { path }\end{array}$ & & & - \\
\hline
\end{tabular}

Ket : $t$ tabel two tailed Pr (/r/。 t tabel), pada DF $=7$ (ghozali, Imam, 2005, h.374)

Alpha () 0,01 t tabel $=3,49$

Alpha () $0,02 \quad t$ tabel $=2,998$

Alpha ()0,025 t tabel $=2,365$

Alpha () 0,10 t tabel $=1,895$

Alpha'() $0,20 \quad t$ tabel $=1,415$

Tabel 3.6.

Hipotesis Penelitian yg Signifikan

\begin{tabular}{|l|l|}
\hline $\mathrm{H}$ & \multicolumn{1}{|c|}{ Hipotesis } \\
\hline $\mathrm{H} 1 \mathrm{c}$ & $\begin{array}{l}\text { Pada waktu persepsi konsumen tentang suasana lingkungan toko menjadi } \\
\text { lebih baik, konsumen akan menganggap biaya moneter yang dikeluarkan } \\
\text { menjadi lebih tinggi (+). }\end{array}$ \\
\hline $\mathrm{H} 1 \mathrm{~d}$ & $\begin{array}{l}\text { Pada waktu persepsi konsumen tentang suasana lingkungan toko menjadi } \\
\text { lebih baik, konsumen akan menganggap kualitas pelayanan dari karyawan } \\
\text { toko menjadi lebih baik(+). }\end{array}$ \\
\hline $\mathrm{H} 1 \mathrm{e}$ & $\begin{array}{l}\text { Pada waktu persepsi konsumen tentang desain toko menjadi lebih baik, } \\
\text { konsumen akan menganggap kualitas barang dagangan yang tersedia } \\
\text { menjadi lebih baik/bagus (+). }\end{array}$ \\
\hline $\mathrm{H} 2 \mathrm{~d}$ & $\begin{array}{l}\text { Pada waktu persepsi konsumen tentang karyawan toko menjadi lebih baik, } \\
\text { konsumen akan menganggap kualitas pelayanan karyawan menjadi lebih } \\
\text { tinggi }(+) .\end{array}$ \\
\hline $\mathrm{H3d}$ & $\begin{array}{l}\text { Pada waktu persepsi konsumen tentang adanya musik di dalam toko } \\
\text { menjadi lebih baik, konsumen akan menganggap kualitas pelayanan } \\
\text { karyawan menjadi lebih baik(+). }\end{array}$ \\
\hline $\mathrm{H3e}$ & $\begin{array}{l}\text { Pada waktu persepsi konsumen tentang adanya musik di dalam toko } \\
\text { menjadi lebih baik, konsumen akan menganggap kualitas merchandise } \\
\text { menjadi lebih tinggi( }+ \text { ). }\end{array}$ \\
\hline $\mathrm{H4}$ & $\begin{array}{l}\text { Semakin tinggi persepsi konsumen akan kualitas merchandise, akan menjadi } \\
\text { lebih tinggi juga persepsi konsumen tentang nilai merchandise itu } \\
\text { nantinya(+). }\end{array}$ \\
\hline
\end{tabular}




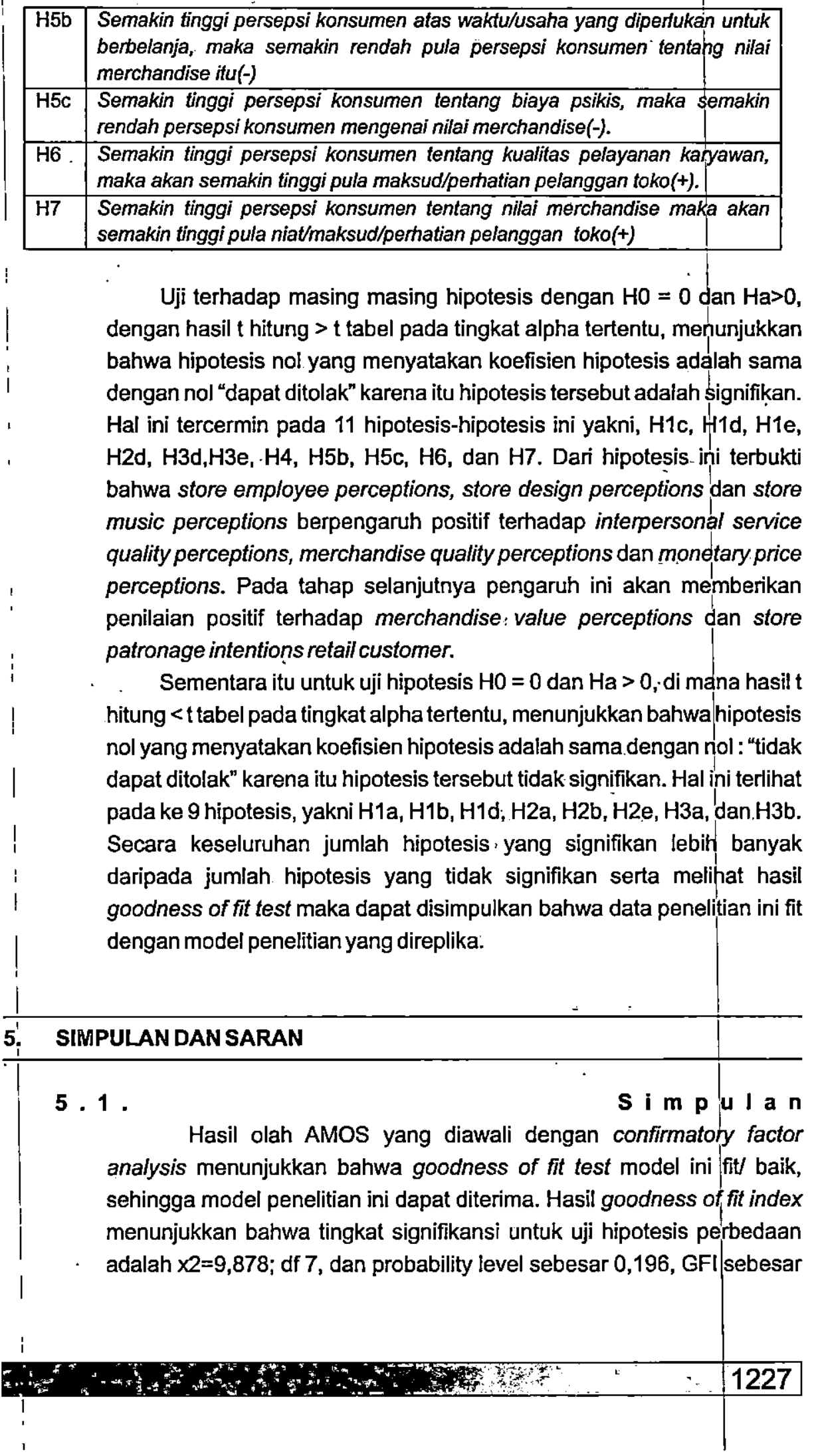


0,987; AGFI sebesar 0,935; TLI sebesar 0,971 ; $C F I$ senilai 0,993 serta RMSEA senilai 0,047 memberikan konfirmasi bahwa nilai-nilai tersebut berada dalam rentang nilai yang diharapkan dan karena itu model penelitian ini dapat diterima/ fit.

Hasil uji kausalitas menunjukkan bahwa kesebelas hipotesis signifikan dan sembilan hipotesis tidak signifikan. Terbukti bahwa store employee perceptions, store design perceptions dan store music perceptions berpengaruh positif terhadap interpersonal service quality perceptions, merchandise quality perceptions dan monetary price perceptions. Pada tahap selanjutnya pengaruh ini akan memberikan penilaian positif terhadap merchandise value perceptions dan store patronage intentions retail customer. Jumlah hipotesis yang signifikan (11) lebih banyak daripada jumlah hipotesis yang tidak signifikan (9) maka dapat disimpulkan bahwa data penelitian ini fit dengan model penelitian yang direplika. Dapat disimpulkan bahwa secara keseluruhan hasil penelitian ini dapat membuktikan hipotesis yang diajukan.

\subsection{Saran}

Setiap bisnis ritel perlu memperhatikan faktor-faktor atau dimensi yang membentuk variabel laten seperti musik, desain toko, dan karyawan pramuniaga. Demikian juga dimensi pelayanan, kualitas barang, biaya (satuan moneter), waktu dan usaha yang dikeluarkan oleh konsumen. Dimensi-dimensi berpengaruh terhadap nilai barang dagangan yang disediakan dan pada tahapan paling akhir mempengaruhi perhatian/ketertarikan pelanggan toko.

\subsection{Keterbatasan Penelitian}

Penelitian ini mereplika model penelitian sebelumnya, namun tidak semua hipotesa ikut diuji. Hal ini dikarenakan keterbatasan alat uji atau software AMOS yang digunakan untuk mengolah data. Amos yang digunakan adalah AMOS versi pendidikan, yang berakibat jumlah variabel yang bisa diolah terbatas. Dengan demikian beberapa hipotesis yang sudah terwakili oleh hipotesis lain menjadi tidak ikut dieji. 


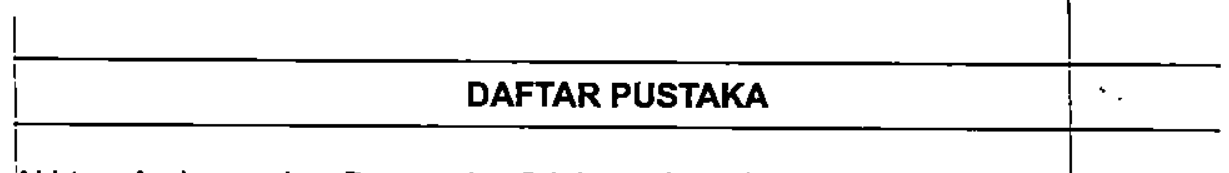

Akhter, Andrews dan Durvasula, Srinivas, (1994),"The Influence of Retail Store Environment on Brand-Related Judgments" Journal of Retailing and Consumer Senvices, Vol.1, Januari, p.67-76

Árbuckle, James (1992), AMOS ${ }^{\top M}$ 3.1 Documentation Package, Department of Psychology, Tmple University, Philadelphia, Pennsylvania, 19122

Assael, Henry, (1995), “Consumer Behaviorand Marketing Action, "Edisi 15, SouthWestern College, Publishing Cincinnati, Ohio.

I

Babin, Barry J.dan William R Darden, (1996), "Good and Bad Shopping Vibes: Spending and Patronage Satisfaction," Journal of Business Research, Vol 35, Maret, p.201-206

Badrun, Abdul Muid, 2006, Yogyakarta Kota Belanja, Kedaulatan Rakyat, Februari, Yogyakarta.

Baker J.,AParasuraman, Dhruv Grewal, dan Glenn B Voss, (2002), "The Influence of Multiple Store Environment Cues on Perceived Merchandise Value and Patronage Intentions" Journal of Marketing, Chicago, April, Vol 66, Iss 2.

Berman, Barry dan Joel R. Evans (1995),"Retail Management A Strategic Approach," Prentice Halls, New Jersey.

Berry, Leonard L dan A.Parasuraman (1996), "The Behavioral Consequences of service Quality," Joumal of Marketing, Vol60,April, p.31-46.

Bellizzi, Joseph A., Ayn E Crowley, and Ronald W.Hasty (1983), "The Effects of Color in Store Design", Journal of Retailing , 59 Spring, p.21-45

Bitner, Mary Jo (1992), “ Servicescape: The Impact of Physical Surroundings on Customers and Employees," Journal of Marketing, 56April, p.57-71

Bruner, Gordon C, (1990),"Music, Mood and Marketing," Journal of Marketing, October, Vol 54, p. $94-104$

Bưchanan L, Carolyn J Simmons , dan Barbara A Bickart,(1999)," Brand Equity Dilution: Retailer Display and Context Brand Effects," Journal of 
Marketing Research, Vol XXXVI, 345-355

Byrne Barbara M. (1998), "Structural Equation Modeling with LISREL, PRELIS, and SIMPLIS: Basic Concepts, Applications and Programming," Lawrence Erlbaum Associates, Publishers, Mahwah, New Jersey, London

Cooper \& Emory (1995), Business Research Methods, 5 th ed, Richard D. IRWIN, Inc.

Crask, Melvin, et.al (1995), Marketing Research: Principal and Applications, Englewood Cliffs, New Jersey, Prentice-Hall , Inc.

Erogiu, and Karen A.Machleit (1990), "An Empirical Study of Retail Crowding: Antecedents and Consequences", Journal of Retailing, 66 Summer, p. . 201-221

Ferdinand, Augusty, (2005), Structural Equation Modelling dalam Penelitian Manajemen, edisi 3, Badan Penerbit UNDIP, Semarang.

Ghozali, Imam, (2005), Structural Equation Modelling, Teori, Konsep dan Aplikasi, Badan Penerbit UNDIP, Semarang.

Greenland, Steven J, dan Peter Mc.Goldrick P, (1994), "Atmospherics, Attitudes and Behavior: Modelling the Impact of Designed Space," The International Review od Retail, Distribution and Consumer Research, January, Vol4, p.1-16

Grewal, Dhruv, dan Julie Baker, (1994), "Do retail Store Environment Factors Affect Consumers'Price Acceptability? An Empirical Examination," International Journal of Research in Marketing, Vol 11, (2)p. 107-115

Hair, Joseph F. et. al (1998), Multivariate Data Analysis, A Simon \& Schuster Company, Upper Saddle River, Prentice- Hall International, Inc. New Jersey.

Hartline, Michael D dan Ferrel, (1996), "The Management of Customer-Contact Service Employees," Journal of Marketing, Vol. 60, Oktober, p.52-70

Jiang, Pingjun, dan Bert Rosenbloom, (2005), "Customer Intention to return online: Price Perception, Attribute-level Performance, and Satisfactions Unfolding Over Time, " European Journal of Marketing, Vol39, p.150 


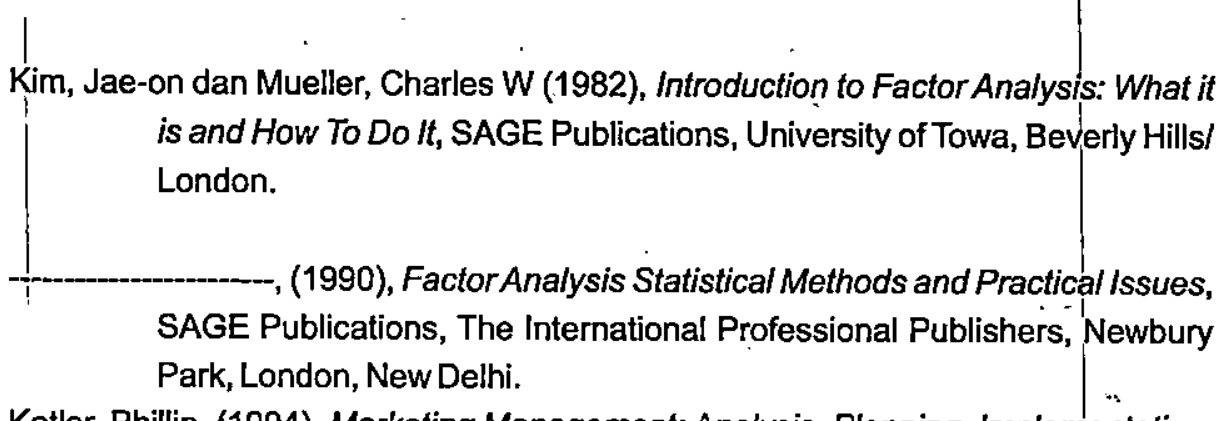

Kotler, Phillip, (1994), Marketing Management: Analysis, Planning, Implementation, and Control, $9^{\text {th }}$ ed. Englewood Cliffs, NJ: Prentice-Hall, Inc.

Lóng, J Scott (1990), Confirmatory Factor Analysis A Preface to LISREL, SAGE Publications, The International Professional Publishers, Newbury Park London New Delhi, Series/ Number 07-033

Milliman, Ronald. E, (1982)," Using Background Music to Affect the Behavior of Supermarket Shoppers, "Journal of Marketing, Vol46, Summer, p.86-91

Parsons L.J., dan W.Bailey Price (1972), "Adaptive Pricing by a Retailer," Journal of Marketing Research, Vol IX, Mei, p.127-133

Rao, Akshay R dan Kent B. Monroe, (1989), "The Effect of Price, Brand Name, and Store Name on Buyers' Perceptions of Product Quality: An Integrative Review," Journal of Marketing Research, VolXXVI, p. 351-357

Santoso, Singgih (2000), SPSS: Mengolah Data Statistik Secara Profesional, Elex Media Komputindo, Jakarta.

Sekaran, Uma (1992), Research Methods For Business: A Skill Building Approach, Second Edition, New York Chichester Brisbone Toronto Singapore, John Willey \& Sons, Inc.

Sharma, Subhash (1996), Applied Multivariate Technique, John Wiley \& Sons, Inc. New York Chichester, Brisbane, Toronto Singapore.

Spies, Hesse, Loesch, (1997), "Store Atmosphere, Mood, and Purchasing Behavior," International Joumal of Research in Marketing, Vol 14] p. 1-17

Stratton, Valerie N (1992), "Influences of Music and Socializing on Perceived Stress

While Waiting," Journal of Marketing Vol 75, Januari, p.334 
Sullivan, Malcom, (2002)," The Impact of Pitch, Volume, and Tempo on the Atmospheric Effects of Music," International Journal of Retail and Distribution Management, "Vol 30, p.323-330

Thoyib, Usman, 1998, Manajemen Perdagangan Eceran, Jilid 1, Ekonisia, Fak Ekonomi Ull, Yogyakarta.

Wheatley, John J dan John S.Y Chiu,(1977), "The Effects of Price, Store Image, and Product and Respondent Characteristics on Perceptions of Quality," Journal of Marketing Research, Vol XIV, p. 181-186

Woodruf, Robert B,(1997), "Customer Value: The Next Source of Competitive Advantage," Journal of the Academy of Marketing Science, Vol 25, Spring, p.139-153

Zeithamal's, (1988)," SERVQUAL: A Multiple-ltem Scale for Measuring Consumer Perceptions of Service Quality, ${ }^{n}$ Journal of Retailing, 64 (Spring), p.12-40 